\title{
Origins of the Chicago Urban Forest: Composition and Structure in Relation to Presettlement Vegetation and Modern Land Use
}

\author{
Robert T. Fahey, Marlin L. Bowles, and Jeanette L. McBride
}

\begin{abstract}
Urban forests provide important ecosystem services, but species composition and canopy structure influence provisioning of these services and long-term stability of the urban canopy. Two landscape-scale data sets (presettlement land surveys and an urban tree census) were used to explore relationships among modern land use, presettlement vegetation, and urban forest canopy structure, size structure, and composition in the Chicago, Illinois, U.S., metropolitan region. Presettlement vegetation and modern land use combined to influence urban forest composition and structure. Modern forested areas with high native species dominance, canopy cover, and structural complexity were associated with forest (rather than prairie) vegetation in the presettlement landscape. Oaks (Quercus spp.), which dominated presettlement forests and provide high ecosystem service value because of their large stature and wildlife value, were strongly associated with presettlement forest areas and modern natural areas. The Chicago region is in a transitional state where composition and structure of larger size classes is heavily tied to pre-urban vegetation. In the future, this landscape is likely to experience a shift in dominance from oaks to smaller-statured, shorter-lived non-native and opportunistic species. This shift, along with climatic change and introduction of exotic pests, may result in an urban forest with reduced potential to provide important ecosystem services.

Key Words. Canopy Structure; Chicago; Ecosystem Services; Land Use; Oak; Presettlement; Quercus; Urban Forest.
\end{abstract}

Urban forests are increasingly being recognized for their ability to provide ecosystem services, such as mitigation of urban heat island effects, water retention/filtration, and carbon sequestration (Zipperer et al. 1997; Nowak et al. 2001a; Pickett et al. 2008). The composition and structure of the urban forest have a very strong influence on its potential to provide ecosystem services (Nowak and Crane 2000). For example, long-lived, large trees have an especially high potential to sequester carbon and to reduce heat exchange and moderate high temperatures through shading and evapotranspirational cooling (McPherson et al. 1997). The makeup of the urban forest likely varies quite strongly across the patchwork of land use types that compose a metropolitan region, which include traditionally defined urban forests in residential and commercial/industrial areas, as well as protected natural areas and parks (Zipperer et al. 1997). Across this mosaic, the composition and structure of the urban forest are related to a variety of drivers, including patterns of pre-urban vegetation, historic, post-settlement and modern land use, underlying geomorphology, and climate (Rowntree 1984a; Rowntree 1986). However, exactly how and why composition and structure vary across the wide range of forest types that make up a metropolitan urban landscape is often not well understood.

Naturally occurring vegetation is an important driver of composition and structure in urban forests (Nowak 1994). However, the degree to which the urban forest is related to historic vegetation patterns depends on the environment and the nature of the pre-urban landscape (McBride and Jacobs 1986; Nowak 1993). For example, urban tree cover is greater in cities that developed in naturally forested areas (Nowak et al. 1996). In such regions, urban areas have remnant, transitional, and emergent stands as significant components of the urban forest (Zipperer 2002). In desert regions, urban forests are largely a product of planting patterns because of the lack of emergent forest development (Walker et al. 2009). The vegetation of the Chicago, Illinois, U.S., metropolitan region (referred to hereafter as the "Chicago region") was historically controlled by an interaction between landscape fire breaks and fire processes related largely to American Indian activity (McBride and Bowles 2001). In this region, frequent fire maintained prairie and oak savanna in much of the landscape, but more closed-canopy forests dominated by oak (Quercus spp.), maple (Acer spp.), and ash (Fraxinus spp.) developed where fire had less impact, such as on the east side of waterways (Bowles et al. 1994). Therefore, the urban forest of the Chicago region is superimposed on a dynamic landscape, which although having a complex preurban vegetation pattern, is generally amenable to the development of closed-canopy forests in the absence of frequent disturbance.

In addition to pre-urban vegetation, patterns of historic settlement and modern urban development are likely to have a strong impact on the composition and structure of the urban forest. Timing of settlement and development affect forest structure (Nowak 1993; Boone et al. 2010) and pattern of development may also be important. For example, one would 
expect that areas with an agricultural period prior to urban development (as with much of the Chicago region) may be more likely to be dominated by emergent than remnant stands. Modern land use can also have an important influence on urban vegetation, but this effect is often not straightforward. The impact of land use is mediated by social factors (e.g., not all residential areas are equivalent; Iverson and Cook 2000; Grove et al. 2006) and can exhibit lag times because of the long life-span of trees relative to patterns of social change (Boone et al. 2010).

Interactive relationships between modern land use and historic vegetation may also exist, which could complicate interpretation of the drivers of urban forest structure and also influence the potential for different sectors of the urban forest landscape to provide ecosystem services. For example, large remnant oaks found in the Chicago region are probably more likely to occur in areas that were forest or woodland in the pre-urban landscape no matter what the modern land use is. However, such trees may also be more common in protected natural areas than in highly developed portions of the urban landscape where lower value emergent forests are more likely to dominate (Zipperer 2002). In a region such as Chicago, where much of the original landscape was not dominated by forest, researchers may expect the distribution of emergent forests to be associated with historic prairie locations and the agricultural development that occurred in these areas. Beyond providing lower levels of ecosystem services, these emergent forests may also be more strongly negatively affected by invasive exotic species than forest remnants, but the relationship between susceptibility to invasion and intactness of forest ecosystems has been mixed (Martin and Marks 2006).

In order to make informed decisions about the future of the urban forest, managers and planners need to understand how the current composition and structure of the forest developed, how it varies across a mosaic of modern land uses and historic ecosystems, and how this composition might affect a provisioning of ecosystem services in the future. The primary objective of this research was to address these needs by investigating patterns in species composition and forest structure across the urban forest continuum of the Chicago metropolitan region. Specific research questions include: 1) What are the primary gradients in species composition and structure in the urban forest? 2) How do these factors vary with modern land use and presettlement vegetation condition? 3) How do original vegetation pattern and modern land use interact to affect composition and structure across the urban forest? and 4) How have composition, structure, and species distributions changed from presettlement to the modern urban landscape?

\section{METHODS}

\section{Study Area}

Chicago is the third largest metropolitan area in the United States, with an estimated population of 9.6 million in an area of $24,814 \mathrm{~km}^{2}$ that spreads across three states (Illinois, Indiana, and Wisconsin). The study area for this analysis was the Illinois subset of the overall metropolitan region, encompassing the seven counties of northeastern Illinois: Cook, DuPage, Kane, Kendall, Lake, McHenry, and Will (Figure 1). The Chicago metropolitan region is composed of a wide variety of land uses, cultural and social milieus, population densities, and around 145,686 ha of natural reserves. Chicago is one of the largest transport hubs in the country, and for this reason is also a locus for introduction of exotic species, including forest pests like the Asian longhorned beetle (Anoplophora glabripennis) and emerald ash borer (Agrilus planipennis), and invasive plant species like European buckthorn (Rhamnus cathartica L.).

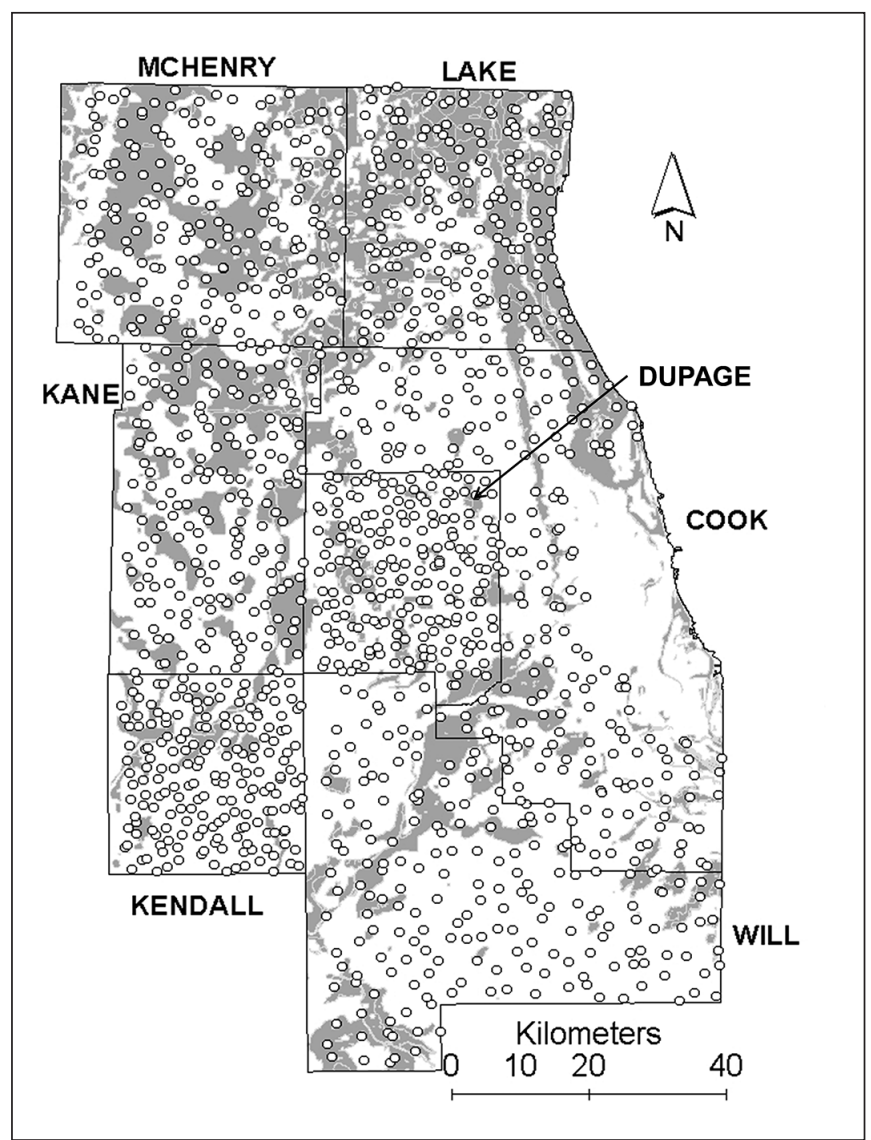

Figure 1. Map showing the Chicago metropolitan region with the seven counties that constituted the study area outlined. Urban Tree Census plot locations are indicated as shaded areas, representing locations recorded as timber in presettlement surveys.

The surficial geology of the Chicago region represents Woodfordian-aged glacial material deposited in the last 20,000 years with glacial drift (end moraines, till plains, and outwash) in the north, west, and south , and the former bed of glacial Lake Chicago in the east-central parts of the region (Willman 1971). Predominant substrates include fine-textured silt-loams and clay-loams in glacial till and lake bed deposits; sands in outwash, lake plain deposits, and beach ridges; coarse-textured gravels in kames, eskers, and valley train deposits; and dolomite bedrock exposed along the major river valleys (Fehrenbacher et al. 1984). The study region has a humid continental climate with mean temperatures of $23^{\circ} \mathrm{C}$ in July and $-6^{\circ} \mathrm{C}$ in January, and mean annual precipitation of 92 $\mathrm{cm}$ (based on climate normals from Illinois State Climatology; Angel 2011). This area is located within the "Prairie Peninsula" (Transeau 1935), a region with unpredictable summer drought (Borchert 1950) that may impact tree growth and survivorship.

The presettlement landscape of the Chicago region was about $60 \%-80 \%$ grassland, with the remainder comprising a savanna- 
woodland-forest gradient corresponding to greater landscapescale fire protection (Bowles et al. 1994; McBride and Bowles 2001). Bur oak (Quercus macrocarpa) and white oak (Q. alba) dominated savanna vegetation, while white oak, black oak $(Q$. velutina), and red oak ( $Q$. rubra) dominated dry-mesic woodlands and forests. White oaks also had a tendency to dominate mesic forests, but sugar maple (Acer saccharum), white ash (Fraxinus americana), and basswood (Tilia americana) were also present. Forests in poorly drained habitats were dominated by swamp white oak ( $Q$. bicolor), American elm (Ulmus americana), green ash (F. pennsylvanica), and soft maple (A. saccharinum).

\section{Data Sources}

Presettlement land survey data were collected by the Government Land Office Public Land Survey (PLS) in 1820-1837. This survey comprised a square-mile landscape grid where the identity, diameter, distance, and direction of one to four bearing trees were recorded at half-mile intervals. These data were accompanied by measures of vegetation intercepted along section lines, as well as township plats distinguishing timber, prairie, and other important landscape features. Despite evidence for biased or non-random selection of bearing trees (Manies et al. 2001), the PLS data and maps represent a large-scale vegetation survey that can be used to reconstruct landscape-scale pre-European vegetation composition and pattern (Manies and Mladenoff 2000). A database and vegetation map shape files were prepared from the Chicago region PLS notes (http://plant conservation.us/plsmap.phtml) to calculate species basal area from bearing trees and to provide overlays of the following presettlement vegetation categories: barrens, lake, marsh, prairie, river, scattering timber, slough, swamp, timber, and wet prairie.

Urban tree census data were collected by The Morton Arboretum in conjunction with the USDA Forest Service in the summer of 2010. A set of 1400 plots were located within the seven county region (excluding the City of Chicago), plot locations were random, but stratified by county (number of plots was equal in each county regardless of area). Plots were 0.04 ha in area (11.3 m radius) and were established regardless of land use or condition. Data collection followed i-Tree Eco protocols (Nowak et al. 2008) and field crews recorded tree species, height, crown spread, crown base height, DBH, crown health/dieback, percent tree cover, shrub cover, and groundcover classes. Crews also classified each plot into one of the following land use categories: agriculture, cemetery, commercial, golf course, industrial, institutional, multi-family residential, other, park (included natural areas), residential, transportation, utility, vacant, and water/ wetland. Of the 1400 plots, 565 had trees present $(\sim 40 \%)$ and were of use in analysis of urban forest composition and structure.

\section{Data Analysis}

Question \#1: What are the primary gradients in species composition and structure in the urban forest?

To illustrate dominant gradients in tree species composition in the modern urban forest, non-metric multidimensional scaling (NMS) ordination was performed on a matrix containing tree census plots and basal area by species. Gradients in canopy structure were evaluated using a principal components analysis (PCA) ordination. Details on ordination methods can be found in Mc-
Cune and Grace (2002). Variables describing canopy structure included total crown volume, average crown depth, total canopy depth, average crown area, maximum canopy height, average canopy height, variance in crown depth, percent tree cover, percent shrub cover, average height to live crown, minimum height to live crown, average crown width, maximum crown width, and crown light exposure. Potential drivers of species composition and structure (median income, housing density, distance to river, distance to road, presettlement density) were overlaid as biplots on both ordinations to assess their correlation with the solution. NMS ordination was conducted in PC-ORD v.5 (McCune and Mefford 2006) using the "slow and thorough" autopilot setting, which uses 250 runs of real data and 250 Monte Carlo randomizations of the data to assess the robustness of the solution. PCA was also conducted using PC-ORD with a correlation-based cross-products matrix and a randomization test to evaluate significance of principal components (McCune and Mefford 2006). To illustrate size structure, diameter distributions were created for all major species in tree census data. Regression analysis was used to test the relationship between log-transformed basal area and measures of canopy depth, maximum canopy height, and percent canopy cover. These tests were performed with data pooled across all land use categories, and within each category. Because basal area and canopy cover have a tendency to be strongly correlated, especially in open grown stands (Law et al. 1994; Buckley et al. 1999), it was expected that basal area would be an important driver of canopy characteristics in urban stands.

Question \#2: Do species composition and structure vary with modern land use, presettlement vegetation condition, and underlying geomorphology?

Differences in species composition and structure among modern land use categories, presettlement vegetation categories, and physiographic region were tested using a Multi-response Permutation Procedure (MRPP) using Sorensen's distance in PC-ORD v.5 (McCune and Mefford 2006). To evaluate differences in size structure among land use categories, diameter distributions were created for each category (oak, native non-oak, non-native) and compared using $\chi^{2}$ tests.

Question \#3: How do original vegetation pattern and modern land use interact to affect composition and structure across the urban forest?

A factorial analysis in a General Linear Model (GLM) was used to test null hypotheses that composition and structure of the urban forest did not differ among land use categories and presettlement vegetation types, and that these two groups had independent effects. For this analysis, land use categories assigned by the Tree Census were pooled into agriculture $(\mathrm{N}=33)$, developed land $(\mathrm{N}=71$; including commercial, industrial, institutional, transportation, utility), residential ( $\mathrm{N}=302$; including multi-family residential), and parks ( $\mathrm{N}=71$; included natural areas). The "vacant" and "other" categories were not used because of their vague descriptions, while cemeteries, golf courses, and wetlands were not used because of their small sample sizes. The presettlement vegetation categories that were tested were prairie $(\mathrm{N}=294)$ and timber $(\mathrm{N}=183)$, all other categories were too rare to be used. GLM analysis was applied to basal area and dominance of three species groups (oaks, native non-oaks, and non-native species), 
species richness variables (total richness, percent native species, and the ratio of native to alien species), and urban canopy characteristics (canopy depth and maximum height, depth and height variance to mean ratios, percent canopy cover and percent shrub cover). To approximate normal distributions, percentages were arcsine-square root transformed, while other values were log- or square-root transformed. Because of highly skewed data, and unbalanced design, the non-parametric Kruskal-Wallis test was used to compare species-level basal area of dominant trees separately within the land use and presettlement vegetation classes. This analysis tests the null hypothesis that all medians are equal, and does not provide an interaction test of factor independence. All GLM analyses were conducted using NCSS (Hintze 2003).

\section{Question \#4: How have composition, structure, and species distributions changed from presettlement to the modern urban landscape?}

A GIS layer of U.S. census tract groups (an agglomeration of census tracts; U.S. Census Bureau 2011) was used to aggregate data for comparison of presettlement and modern vegetation composition. Each tree census and land survey point was assigned to a census tract group based on its spatial location (tract groups had between 1 and 36 tree census points, mean of 10.4 points per tract group). Relative basal area data from each data set was then calculated at the tract group level and combined into a single matrix. An NMS ordination was performed on the tract group matrix with the same settings as above. Presettlement and modern tract groups were connected with "transitional" vectors in the resulting ordination (McCune and Grace 2002). The length and direction of these vectors, which represent the change in species composition from presettlement to the modern landscape, were compared among modern land use categories using multivariate analysis of variance (MANOVA) with NCSS (Hintze 2003).
To assess spatial patterns in species transitions the presence/ absence of each species at the tract group level was determined for the modern tree census data. Researchers then calculated what proportion of tract groups that had a species present in the modern data also had the species present in the PLS data and compared this value among species. Distributions of the major tree species were also compared visually between the two data sets.

\section{RESULTS}

\section{Patterns of Species Composition and Structure}

Twenty species comprised more than $80 \%$ of the total basal area sampled by the Urban Tree Census (Table 1). Native non-oak species accounted for $44 \%$ of the total basal area, with dominance ranging from about $1.4 \%$ to $7 \%$. Among this group, soft maple was the leading species, followed by box elder (Acer negundo), cottonwood (Populus deltoides), and green ash. Bur oak, white oak, and red oak accounted for $21.5 \%$ of the basal area. Non-native species accounted for an additional $16 \%$ of basal area, in which buckthorn (Rhamnus cathartica) was the leading species. Species dominance was much less even in the PLS (Table 1), with white oak accounting for $41.3 \%$ of basal area, followed by bur oak, American elm, red oak, and black walnut (Juglans nigra). By 2010, all oaks and American elm had declined in dominance, while soft maple, cottonwood, and white ash increased in dominance by several orders of magnitude (Table 1).

NMS ordination of modern urban forest species composition (basal area) produced a three-dimensional solution that explained $43.2 \%$ of the variation in the original species matrix and was significant based on Monte Carlo simulation ( $p=0.004$, Stress $=$ 24.13). None of the potential predictors was strongly related to the ordination axes (all $\mathrm{r}<0.03$ ), but Axis 2 was strongly associated with oak dominance $(r=-0.763$, Figure 2$)$ and also maxi-

Table 1. Comparison of basal area and dominance for species sampled by the Urban Tree Census (2010) and by the U. S. Public Land Survey (1820-1830). Dominance is percentage of total basal area and does not sum to 100 because some minor species were not included. Percent change reflects change in dominance from presettlement to modern, very large values may partly reflect differences in sampling strategy between data sets.

\begin{tabular}{|c|c|c|c|c|c|}
\hline \multirow[b]{2}{*}{ Species } & \multirow[b]{2}{*}{ Species group } & \multicolumn{2}{|c|}{ Urban tree census } & \multicolumn{2}{|c|}{ Public land survey } \\
\hline & & $\begin{array}{l}\text { Basal area } \\
\text { /hectare }\end{array}$ & Dominance & Dominance & $\begin{array}{l}\text { Change in } \\
\text { dominance }(\%)\end{array}$ \\
\hline Quercus alba & Native-oak & 0.80 & 6.97 & 41.28 & -83.12 \\
\hline Quercus macrocarpa & Native-oak & 1.02 & 8.86 & 13.09 & -32.29 \\
\hline Quercus rubra & Native-oak & 0.66 & 5.70 & 6.60 & -13.68 \\
\hline Acer saccharinum & Native non-oak & 1.09 & 9.44 & 0.01 & 80787.98 \\
\hline Acer negundo & Native non-oak & 0.91 & 7.89 & 0.00 & -- \\
\hline Fraxinus pennsylvanica & Native non-oak & 0.57 & 4.97 & 0.00 & -- \\
\hline Prunus serotina & Native non-oak & 0.52 & 4.55 & 0.00 & -- \\
\hline Juglans nigra & Native non-oak & 0.29 & 2.53 & 2.18 & 15.79 \\
\hline Ulmus americana & Native non-oak & 0.29 & 2.50 & 9.03 & -72.32 \\
\hline Gleditsia triacanthos & Native non-oak & 0.26 & 2.21 & 0.00 & -- \\
\hline Fraxinus americana & Native non-oak & 0.24 & 2.07 & 0.14 & 1388.67 \\
\hline Acer saccharum & Native non-oak & 0.23 & 1.98 & 0.97 & 104.78 \\
\hline Rhamnus cathartica & Non-native & 0.52 & 4.55 & 0.00 & -- \\
\hline Ulmus pumila & Non-native & 0.30 & 2.60 & 0.00 & -- \\
\hline Acer platanoides & Non-native & 0.23 & 2.02 & 0.00 & -- \\
\hline Robinia pseudoacacia & Non-native & 0.21 & 1.78 & 0.00 & -- \\
\hline Salix spp. & Non-native & 0.18 & 1.53 & 0.00 & -- \\
\hline Malus spp. & Non-native & 0.16 & 1.37 & 0.00 & -- \\
\hline Total & & 9.39 & 81.44 & 73.32 & \\
\hline
\end{tabular}


mum tree diameter $(r=-0.408)$. There was not a strong separation among land use categories in the ordination space, but presettlement vegetation condition did show a relatively strong gradient (Figure 2). MRPP found no significant difference in species composition among the land use categories $(\mathrm{A}=0.0001, \mathrm{p}=0.35)$, but there was a significant, but not especially strong, difference among presettlement vegetation classes $(A=0.004, p<0.001)$.

PCA of canopy variables yielded a two dimensional solution that explained $65.3 \%$ of the variation in the original data matrix and illustrated two strong gradients in canopy structure (Figure 3). Principal components 1 and 2 explained $45.2 \%$ and $20.1 \%$ of the variation, respectively, and were both highly significant based on randomization tests (eigenvalues 7.22 and 3.28, and both $p$ $=0.001$ ). The first axis was strongly associated with all of the structural variables except percent shrub cover and crown light exposure, and illustrates a strong separation of plots in variables associated with overall canopy volume (Figure 3). The second axis was strongly related to crown light exposure and displayed a dichotomy between plots with large open-grown trees and those with high total canopy volumes. However, none of the predictor variables were strongly associated with either axis (all $r$ $<0.1$ ) and there was not strong separation among land use or presettlement categories in the ordination or based on MRPP analysis (land use: $\mathrm{A}=0.001, \mathrm{p}=0.76$; presettlement: $\mathrm{A}=$ $0.012, \mathrm{p}<0.001 ; \mathrm{A}$ is the chance-corrected within-group agreement, values of $<\sim 0.1$ are considered to indicate low association among group differences even with statistical significance).

All species groups showed a strong negative exponential distribution, although oaks had a much longer "tail" (i.e., greater abundance in large size classes; Figure 4a; Figure 4b). The magnitude of the stem densities in each size class differed greatly between species groups, with smaller size classes strongly dominated by non-native and opportunistic native species such as buckthorn, box elder, and black cherry (Figure 4a; Figure 4c). Some oaks occurred in smaller size classes, but oaks only made up a majority of the stem density in the largest size classes $(>70 \mathrm{~cm}$ DBH; Figure $4 \mathrm{~b})$. Diameter distributions of the three species categories differed significantly among land use categories (oak $\chi^{2}=15.69, \mathrm{p}=0.047$; native nonoak $\chi^{2}=99.57, \mathrm{p}<0.001$; non-native $\left.\chi^{2}=133.37, \mathrm{p}<0.001\right)$.

Basal area had significant $(\mathrm{p}<0.001) \log$-linear positive correlations with canopy depth $\left(r^{2}=0.7571\right)$, maximum canopy height $\left(r^{2}=0.7582\right)$, and percent canopy cover $\left(r^{2}=0.6581\right)$. Similar correlations with each canopy metric were also significant $(\mathrm{p}<0.001)$ at the land use level for agriculture $\left(r^{2}>0.4725\right)$, development $\left(r^{2}\right.$ $>0.7124)$, parks $\left(r^{2}>0.7043\right)$, and residential $\left(r^{2}>0.6348\right)$. Because these relationships were non-linear, a proportionally greater loss of BA corresponded to a linear loss of canopy structure.

\section{Drivers of Composition and Structure}

Mean BA of oaks, native non-oaks, and non-native species varied significantly among land use and presettlement vegetation categories (Table 2). Native species had greater BA in parks and lower BA in developed areas, while non-native species had greater BA under agricultural land use. Only oak BA varied significantly between the PLS vegetation types, with greater BA in former timber habitat (Figure 5b). Only non-native species had a significant interaction, as their BA was greater in former timber under agricultural land use, but greater in parks and residen-

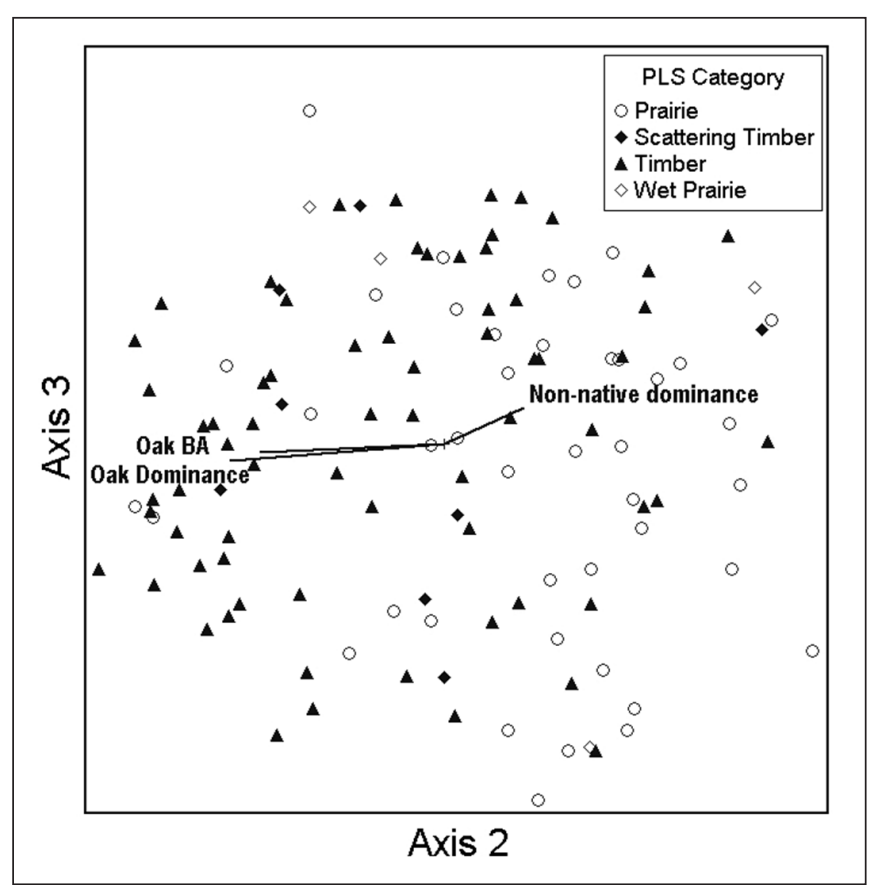

Figure 2. Non-metric multidimensional scaling ordination of tree species composition in Tree Census data with symbols coded by presettlement condition of plots and correlated $(r>0.3)$ variables overlaid.

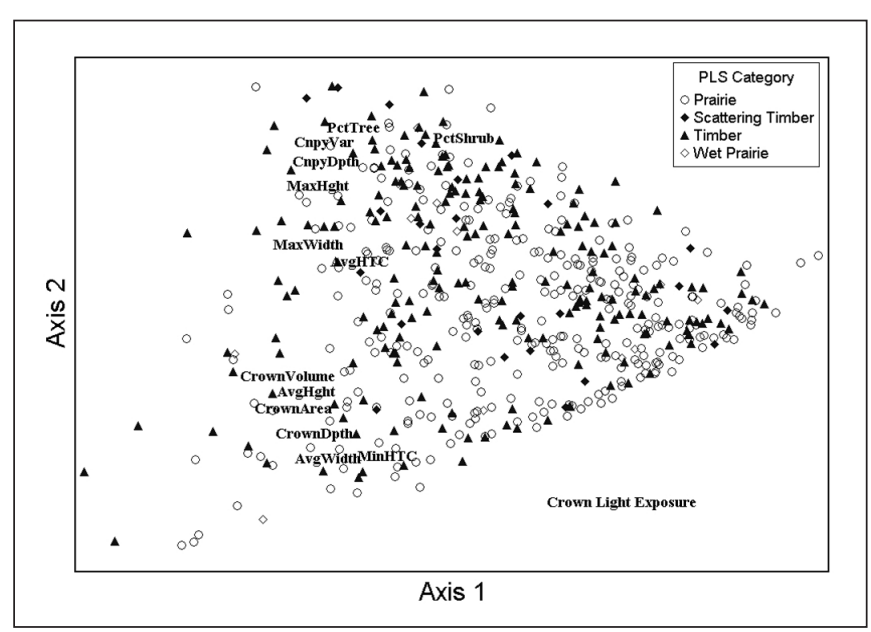

Figure 3. Principal components analysis ordination of canopy structure variables in Tree Census data, with symbols coded by presettlement condition of plots and location of group centroids for canopy structure variables indicated. Canopy variance is the variance to mean ratio of crown volumes within a plot.

tial habitats that were formerly prairie (Table 2). Oak and nonnative dominance varied significantly (Table 2) and inversely (Figure 5a), with greater oak dominance in parks and in former timber, and lower non-native dominance in parks and in timber.

Among measures of species diversity, total species richness and percent native richness varied significantly across the land use and vegetation types, with greater values in parks and former timber habitats, and lower values in developed areas (Table 2). The ratio of native to alien species exceeded 1.0 only in parks, but with marginal $(P=0.08)$ significance. All 


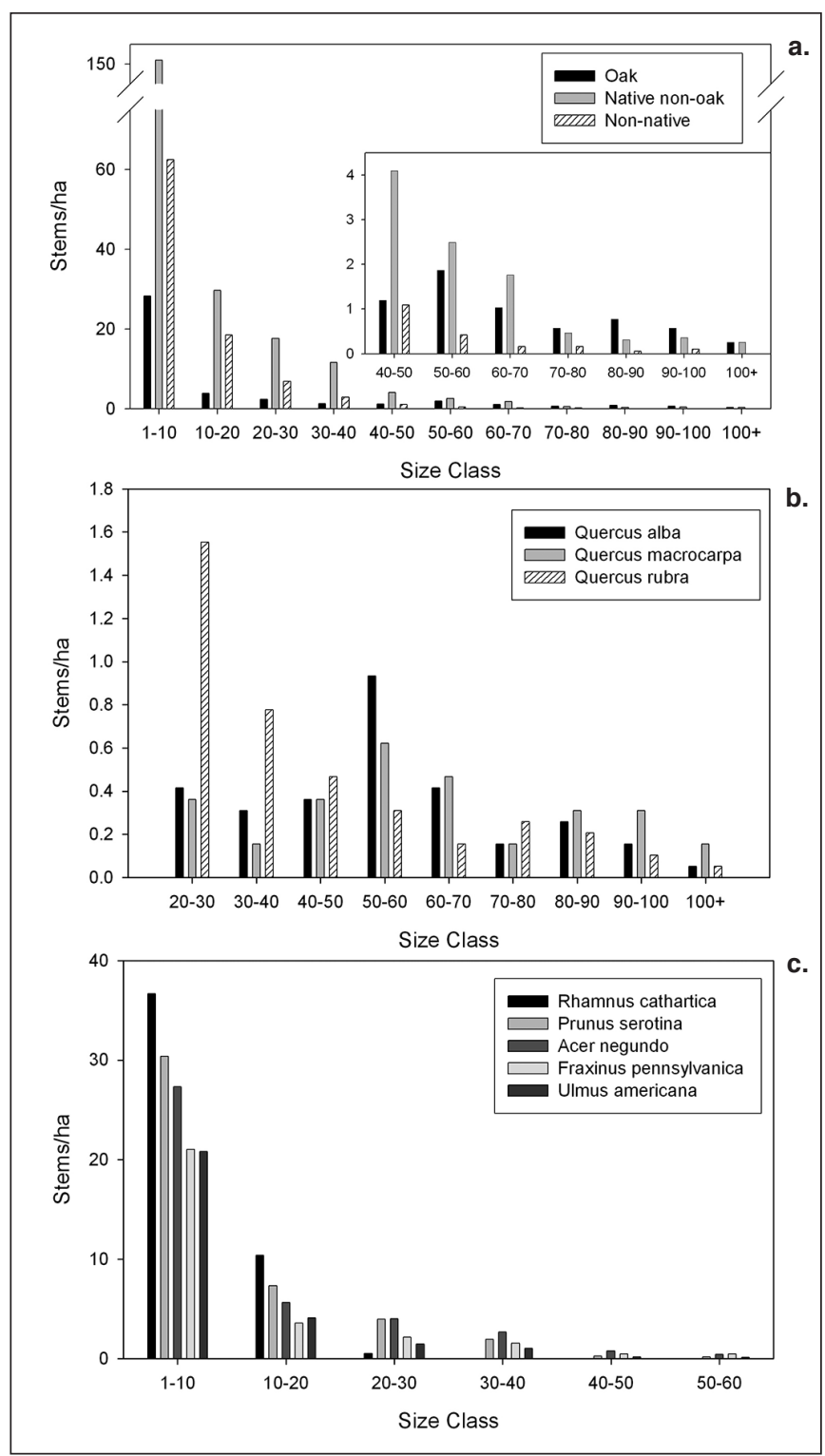

Figure 4. Diameter distributions for a) species categories (with inset showing blowup of large diameter classes), b) oak species in large size classes, and c) dominant native and non-native species in small size classes.

measures differed significantly between PLS vegetation types, with greater richness, percent richness and native:alien ratio in former timber habitat. Although only total richness had a significant interaction, all measures tended to have greater values in former timber habitat only in parks and residential areas.

All canopy and shrub layer characteristics differed significantly among land use and presettlement vegetation-type categories, with higher values in parks and in former timber habitat (Table 2). Only tree canopy cover varied as a significant interaction between presettlement and modern classes, with former timber habitat exhibiting greater values in agricultural, park, and residential land use areas, but not in developed areas.

Among native species, only sugar maple and green ash did not differ significantly in BA across land use types (Table 3). Most species had greater BA in parks, with the exclusion of greater

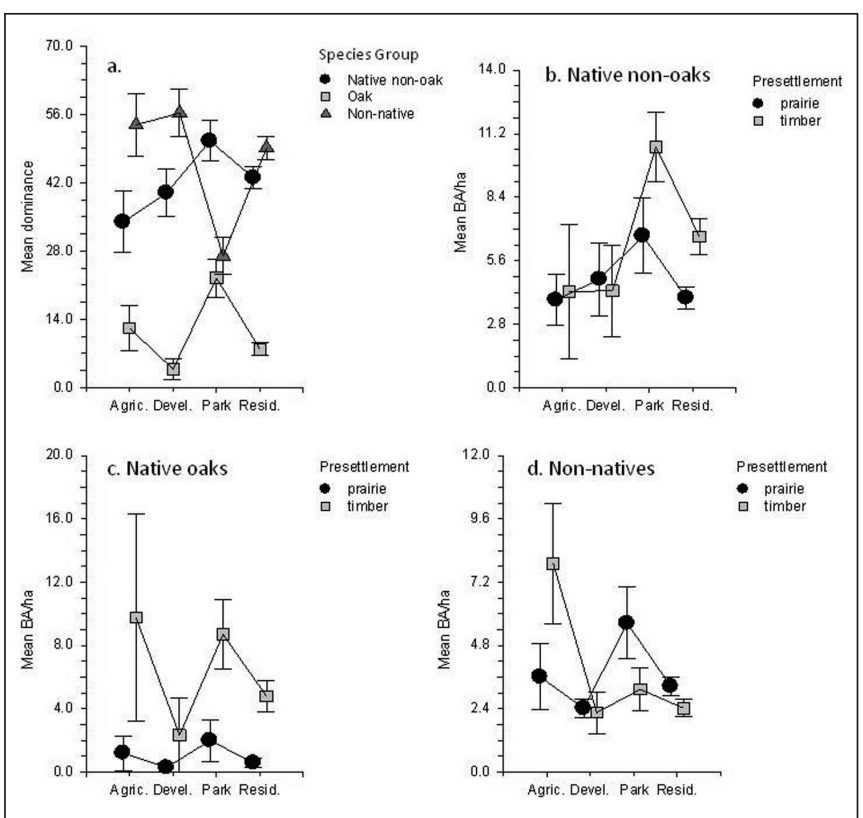

Figure 5. Dominance of species categories by land use and (a) mean basal area/hectare $( \pm S E)$ of individual categories by modern land use and (b-d) presettlement condition.

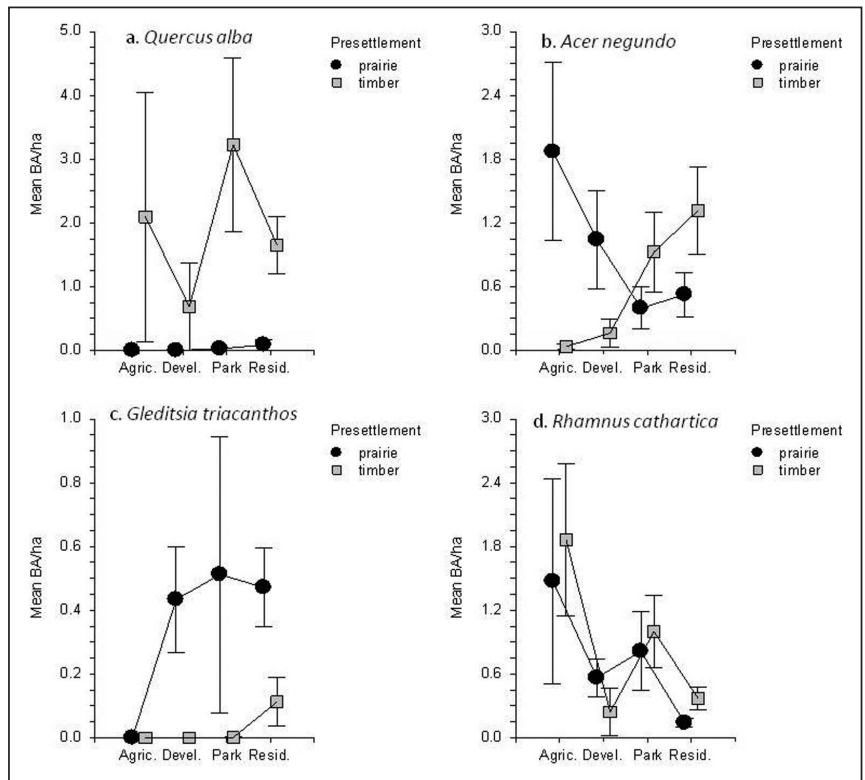

Figure 6 . Mean basal area/hectare $( \pm \mathrm{SE})$ of selected species by land use and presettlement condition.

BA for bur oak and soft maple in agricultural areas and greater BA for honeylocust (Gleditsia triacanthos) in developed areas. Most native species also differed significantly among PLS vegetation types, with greater BA in former timber. Box elder and honeylocust were exceptions, with greater BA in former prairie (Figure 6). Among non-native species, only Malus sp. and buckthorn differed among land use types, both with greater BA in agricultural areas. Only buckthorn differed among PLS vegetation types, with greater BA in former timber (Figure 6). 

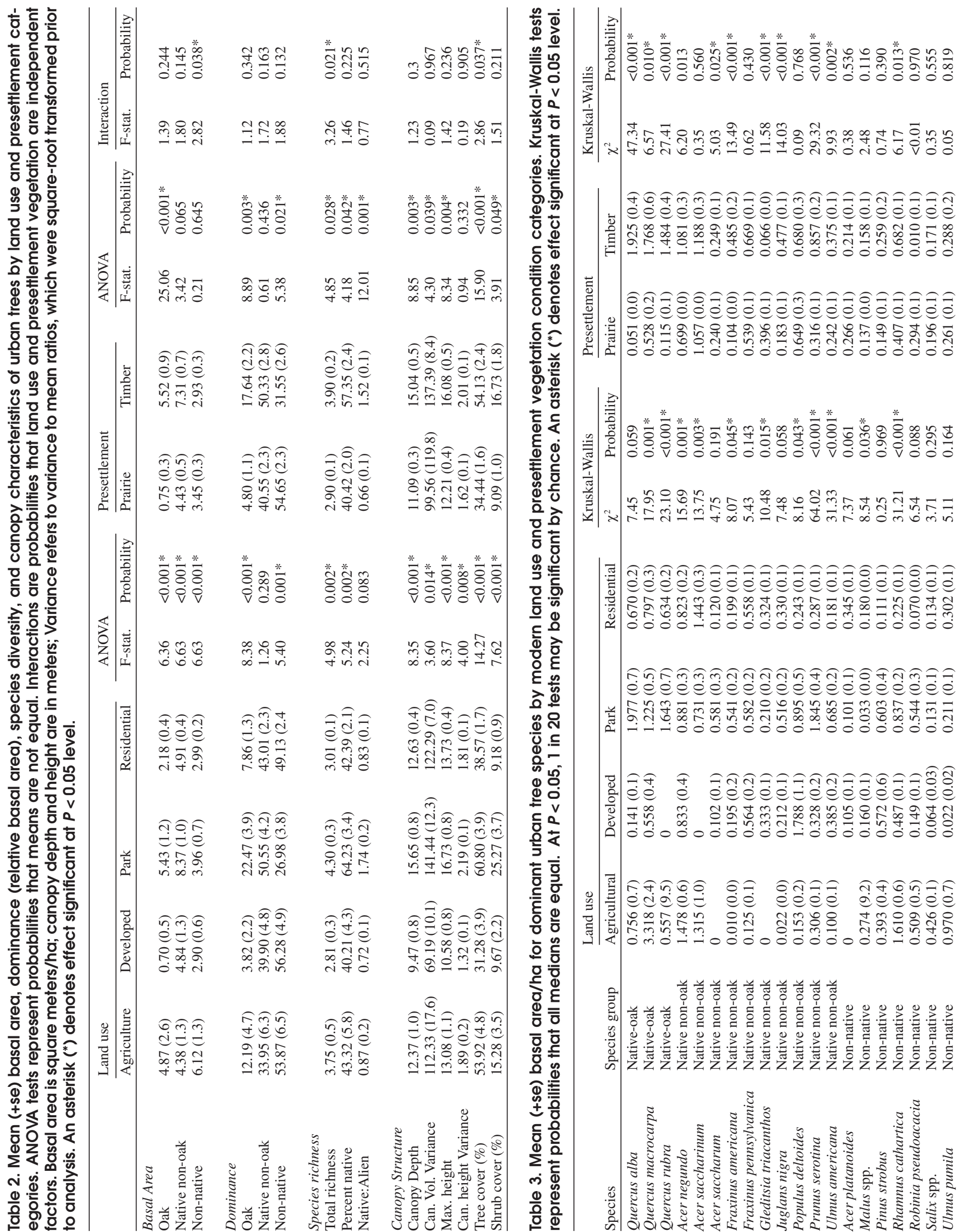


\section{Comparison of Presettlement and Modern Land- scape}

NMS ordination of the tract group species transition matrix produced a three dimensional solution that explained $67 \%$ percent of the variation in the original data matrix and was significant based on Monte Carlo simulation $(p=0.004$, Stress $=25.82)$. There was a strong separation of presettlement and modern composition in the ordination space (Figure 7). However, change in composition from presettlement to modern did not differ among modern land use categories based on MANOVA of transitional vectors (all comparisons $\mathrm{p}>0.1$; vectors not illustrated).

Spatial patterns in presettlement and modern species occurrences also illustrate the transitions in species composition and their reliance on original vegetation. For example, white oak occurrences in the modern landscape largely coincide with locations that had this species present prior to urbanization (Figure 8). In contrast, soft maple occurred only in a few riparian areas in the original landscape, but now is widely spread throughout the region (Figure 8). Also, census tract groups where oak species were present in the modern landscape tended to also have those species present in the presettlement landscape (95\% of modern white oak occurrences, bur oak $-74 \%$, red oak $-53 \%$ ). In comparison, the primary nonoak native species had a far smaller proportion of their modern occurrences associated with presettlement locations (sugar maple $-23 \%$, soft maple $-3 \%$, white ash $-29 \%$, American elm - 29\%).

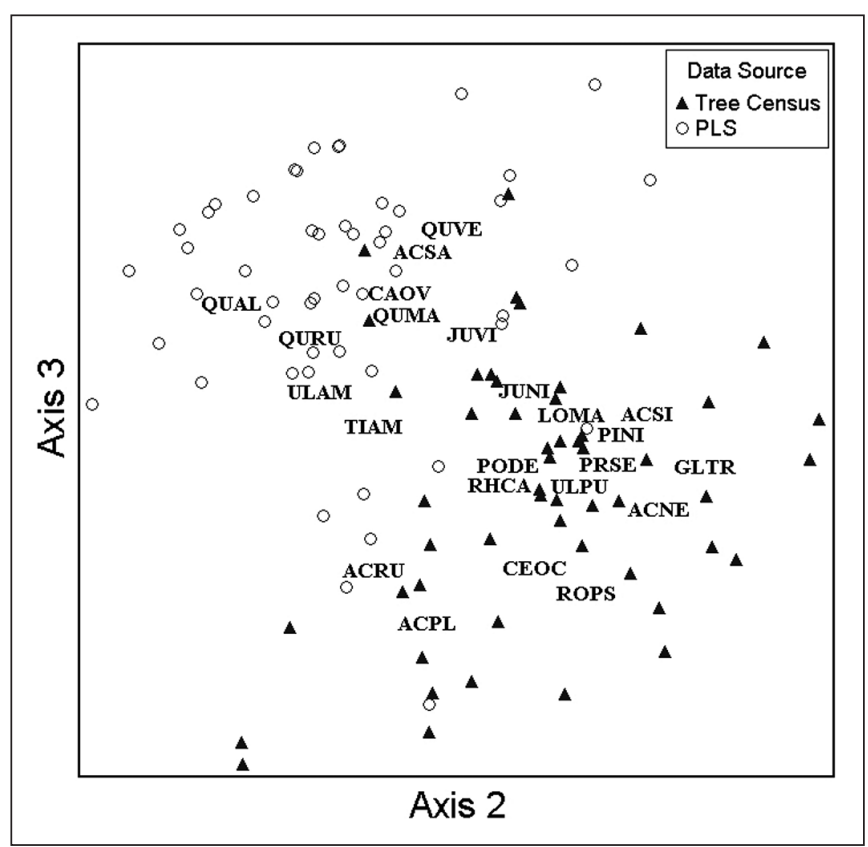

Figure 7. Non-metric multidimensional scaling ordination of tree species composition in Tree Census and presettlement land survey combined at census tract group level, location of group centroids for species are indicated. Species acronyms: ACNE (Acer negundo), ACPL (A. platanoides), ACRU (A. rubrum), ACSA ( $A$. saccharum), ACSI (A. saccharinum), CAOV (Carya ovata), CEOC (Celtis occidentalis), GLTR (Gleditsia triacanthos), JUNI (Juglans nigra), JUVI (Juniperus virginiana), LOMA (Lonicera maackii), PINI (Pinus nigra), PODE (Populus deltoides), PRSE (Prunus serotina), QUAL (Quercus alba), QURU (Q. rubra), QUVE (Q. velutina), QUMA (Q. macrocarpa), RHCA (Rhamnus cathartica), ROPS (Robinia pseudoacacia), TIAM (Tilia americana), ULAM (UImus americana), ULPU (U. pumila).

\section{DISCUSSION}

\section{Influence of Presettlement Vegetation on the Modern Urban Forest}

This is the first landscape-scale study to illustrate the interactive effect of presettlement vegetation pattern (i.e., timber versus prairie) and modern land use on composition and structure of a large metropolitan region urban forest. Previously, McBride and Jacobs (1986) used natural stands as a proxy for presettlement vegetation to show that both original stand condition and urban development affect composition and structure of selected urban forest stands at a local scale. The current data show that presettlement prairie and forest vegetation has played an important role, both directly and indirectly, in the development of the modern urban forest landscape of the Chicago region. One of the most important direct influences is the transition of forested areas in the presettlement landscape into residential and natural areas with greater canopy cover, larger trees, higher species richness, and a greater proportion of native tree species than areas developed from prairie vegetation. As a result, remnant forests stemming from original woodlands appear to have formed the basis for the parts of the urban forest with the highest value from an ecosystem services perspective (Nowak 1994). These areas also had high levels of oak dominance, and much of the value of these stands is likely derived from the presence of large oaks descending from presettlement vegetation. Such trees are known to provide high levels of important ecosystem services, such as wildlife habitat, shade, and carbon storage (McPherson et al. 1994).

The legacy of presettlement vegetation pattern and composition on the urban forest can also be seen in comparisons of spatial patterns of species occurrence between the original and modern landscapes. Present-day occurrences of oaks (the dominant species in the presettlement landscape) are almost exclusively associated with forested areas that had these species present in the original landscape, providing additional evidence for the direct transition of presettlement oak forests into areas with a modern oak component. Patterns of occurrence of individual oak species in relation to specific species traits and adaptations are also informative. For example, basal area of red and white oak, primarily forest and woodland species with moderate shade tolerance, was greatest in parks. On the other hand, basal area values for bur oak, a savanna species with low shade tolerance, were greatest in agricultural areas. This pattern may result from the presence of bur oak, as occasional trees in the presettlement prairie matrix, or its ability to colonize areas with high light availability associated with agricultural abandonment.

Comparisons of spatial pattern and non-native species occurrence also illustrate the important influence that planting patterns and emergent forests have had on species composition. Native species that are either commonly planted in urban areas (such as soft maple; Figure 8) or opportunistically invade open habitats (e.g., box elder; not shown) had the least congruence between original and modern distribution. The importance of emergent, or successional, stands as a component of urban forests has been illustrated by Zipperer (2002), but the combined effect of original vegetation pattern and land use on the development of these forests has not previously been illustrated. As an example, although agricultural and other developed areas (e.g., commercial and industrial) had greater dominance of non-native species than parks 

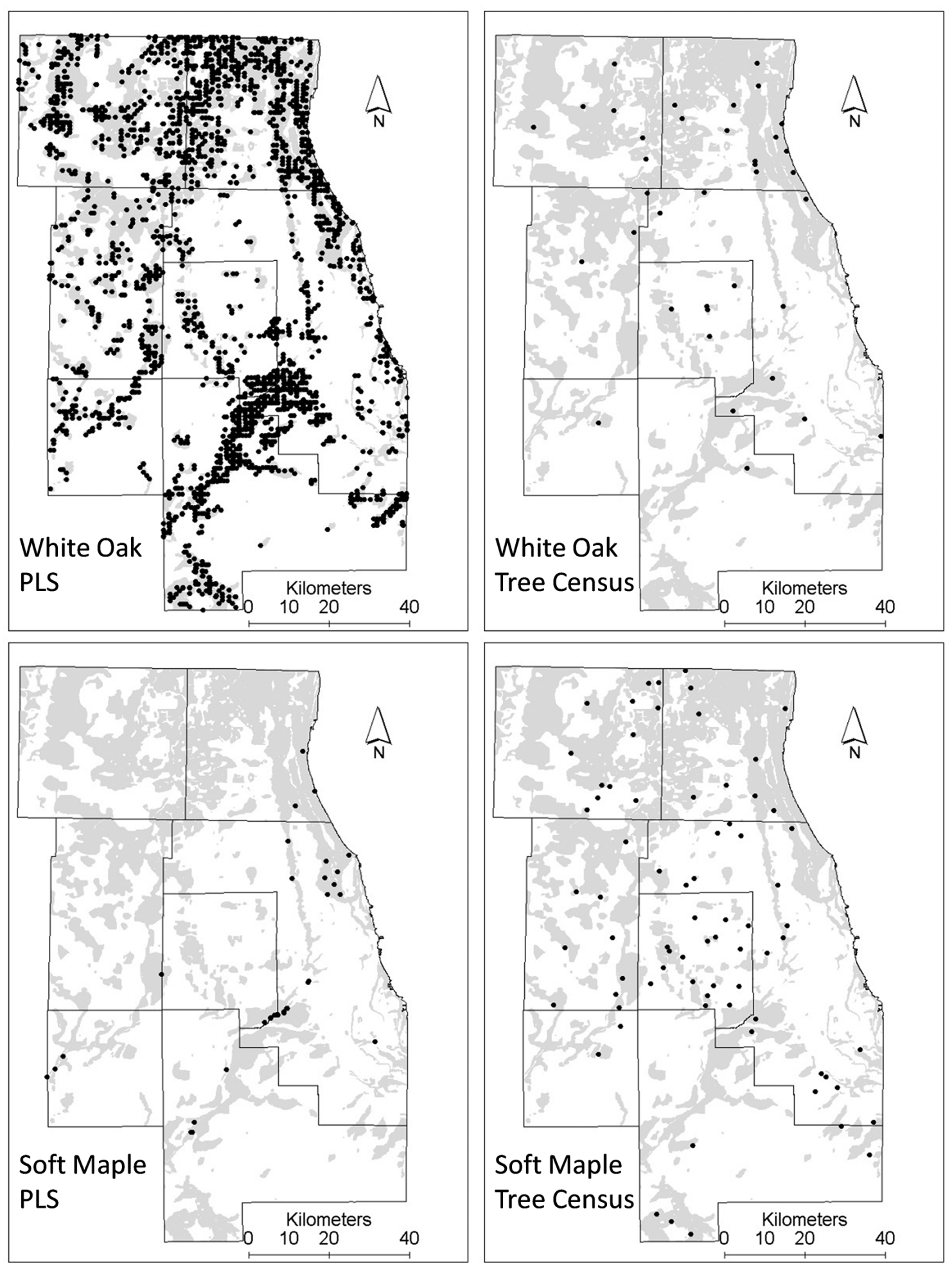

Figure 8. Maps showing presettlement and modern Tree Census locations of a) white oak (Quercus alba), and b) soft maple (Acer saccharinum). Shaded areas represent locations recorded as timber in presettlement surveys. 
and residential areas, these modern land uses had much higher non-native basal area when they developed from former prairies. In most cases it is unlikely that these opportunistic species invaded prairies directly. Rather, these species were either planted during urban development, or were established in open habitat following agricultural abandonment. The lack of an impact of presettlement vegetation on buckthorn is interesting, and may be related to the more recent introduction of this species or to lifehistory traits that allow it to invade intact forests (such as bird dispersal and high shade tolerance). In developed areas, the relative abundance of emergent stands, and the dominance of invasive and opportunistic species in them, likely accounts for the relative lack of canopy structure and high proportion of non-native species.

\section{Variation in Forest Characteristics Across the Urban Forest Continuum}

Although some strong gradients in urban forest composition and structure were evident, there was not a clear link between these characteristics and modern land use. This result is not especially surprising given the strong influence of presettlement condition illustrated here, and previous work in Chicago and other urban systems that has shown inconsistent modern land use-vegetation relationships (Rowntree 1984b). Urban forest condition can be strongly influenced by patterns of early settlement and development (Nowak 1993), and in the case of the Chicago region, modern land uses may reflect a wide variety of development patterns. For example, many residential and commercial areas in the Chicago suburbs were in agricultural land use until very recently, while those in the interior are likely to have been in urban land uses for well over a century. Such lags in development could influence factors such as planting preferences, soil compaction, and likelihood of remnant versus emergent forests.

Another factor that may limit the power of modern land use classes to predict forest composition and structure is the wide variety of site conditions within these categories (Cadenasso et al. 2007). Part of this effect is the nature of categorical data, which necessarily lumps areas with somewhat different characteristics into classes. For example, not all residential areas are equivalent, as areas with high property or income values have been shown to have greater canopy cover (Iverson and Cook 2000). However, there can also be a lag between social factors and forest composition and structure because of the rapid pace of social change relative to forest stand processes, such as tree maturation and mortality (Boone et al. 2010).

Although there were significant differences among land use categories in the dominance of species groups, neither the more desirable (e.g., oaks, native mesic forest species) nor problematic (e.g., invasive exotics and native opportunists) species were absent from any categories. Both native- and exotic-dominated stands can be found across the urban forest continuum. This finding suggests that management focusing completely on either natural forests or traditionally defined urban forests will miss parts of the urban forest continuum that either have important ecosystem value or have the potential to be invasion loci for exotic species. However, canopy and stand structure varied strongly across land use categories, suggesting that the value of the stands in some parts of the urban forest is generally greater than others. Developed areas (e.g., commercial, industrial, transportation, utility, and institutional land uses) had the lowest levels of all relevant metrics, including native species proportion, species richness, canopy cover, and canopy structure. These data appear to support the findings of Zipperer (2002), in that compared to emergent forests, remnant forests have more complex canopy structure and greater diversity in size structure, both of which can be associated with important ecosystem services such as shading (McPherson et al. 1997), and could lead to greater resilience (McBride and Jacobs 1986).

\section{The Future of the Chicago Urban Forest: A Forest in Transition}

The Chicago urban forest appears to be in a transitional state (Figure 9), which could have very important implications for the future of the region and could affect the management paradigm for the regional forest. The size structure evident in this data indicates a likely shift in composition away from oak dominance, as all of the oak species were much less abundant than non-native and opportunistic-native species in smaller size classes. This finding fits with results of studies conducted in natural areas in the region, which have consistently shown a trend of decreasing oak dominance at the expense of mesicsite associated species, such as maple (Bowles et al. 2005). The oak resource in the region is largely even-aged and composed of pre and immediate post-settlement trees (Bowles et al. 2005). The even-aged structure and maturity of the large oaks in the urban forest ( 200 years; Bowles and Jones 2008) suggest a potential precipitous decline in oak canopy dominance in the near future, as these trees reach their natural life-span.

Across the urban forest, smaller size classes are highly dominated by exotic and opportunistic or mesic forest-associated na-

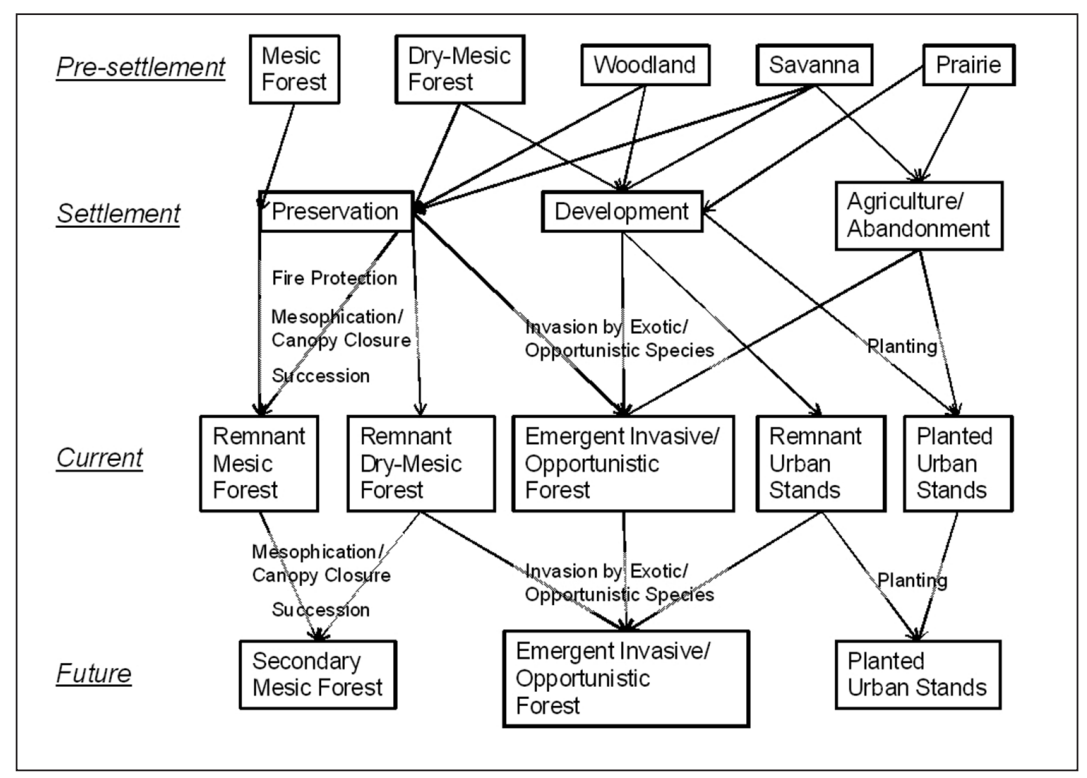

Figure 9. Conceptual model illustrating generalized development of Chicago region urban forest and possible future trajectory. 
tive species. These patterns are indicative of a shift in the overall makeup of the Chicago urban forest from a complex mixture of remnant, emergent, and planted stands, to one more heavily dominated by the latter two categories and lacking in large, old trees (Figure 9). Much effort has been expended attempting to reverse the trend from oak to mesic species dominance in natural areas in the region, but the necessary resources to influence this trend at a landscape-level generally do not exist. Even where resources do exist, the problem of mesophication (replacement of fire-adapted species by mesic site species) has proven to be a difficult one (Nowacki and Abrams 2008), and may be especially complicated in an urban setting because of the difficulty of implementing high intensity prescribed fire and canopy removal treatments. Planting of oaks into urban settings could alleviate the trend away from oak dominance to some extent, and maintain oak canopy in some areas. Such activities are likely reflected in the relatively large number of oak stems in small size classes (as these are mostly absent in natural areas; Bowles et al. 2005). However, a wholesale switch to oak-dominated urban plantings is unlikely and may be unwarranted because of the need to maintain species diversity and landscape resilience in the urban forest (Santamour 2004). A shift in dominance away from oaks and toward short-lived, smaller-statured opportunistic species (whether native or exotic) would probably result in an urban forest that has a much lower potential to provide the ecosystem services that are increasingly being touted as the reason to plant and maintain the urban forest (Nowak et al. 2001a). For example, the high correlation in this analysis between basal area and canopy structure characteristics suggests that the loss of large trees (which has an exponential effect on basal area), and the reduction in dominance of species with the potential to become large, will likely result in decreased overall canopy cover and structural complexity.

The resilience of the urban forest to climatic changes and the introduction of exotic pests may also be affected by the patterns in composition and structure observed in this study. One exotic pest that has recently been introduced and will likely have important impacts on composition and structure is the emerald ash borer. Developed areas with high levels of planted ash trees will be especially hard hit by this pest, but the emerald ash borer will also likely further the shift away from native species dominance across the urban continuum (Poland and McCullough 2006). The Asian longhorned beetle, another potentially devastating forest pest, was detected in Chicago in 1998 and eventually eradicated, but has since become a problem in other urban areas in the U.S. (Haack et al. 2009). The Asian longhorned beetle attacks a wide variety of hosts, including maples and other native species found in both the natural areas and plantings in the Chicago urban forest. An outbreak of this pest would strongly affect the urban forest (Nowak et al. 2001b), especially given the ongoing transition from oak to maple dominance in the region. These and other forest pests could exacerbate the expected loss in ecosystem service potential related to decline in oak dominance. Forecasted changes in regional climate are also likely to impact the urban forest, but the high species richness of the current landscape could help provide resiliency to these changes (Elmqvist et al. 2003). For example, the inclusion of many species with southern ranges and high drought tolerance in urban plantings could help the regional forest respond to predicted climatic changes (Woodall et al. 2010). However, the transitions in composition and structure indicated in this analysis could reduce the species and age diversity of the urban forest and result in reduced overall resiliency to both climate change and exotic pests.

Acknowledgments. Funding for the Urban Tree Census was provided by The Morton Arboretum and USDA Forest Service Northeastern Area State and Private Forestry and for PLS analysis by Chicago Wilderness, USDA Forest Service, U.S. Fish \& Wildlife Service, and Illinois Conservation Foundation. The authors wish to thank all of those involved in coordination and data collection for the Urban Tree Census, and especially Veta Bonnewell for assistance with accessing and manipulating the data. For comments on the manuscript we thank two anonymous reviewers.

\section{LITERATURE CITED}

Angel, J.R. 2011. Illinois Climate Normals (updated to 1981-2010). Illinois State Water Survey, Champaign, IL. <www.isws.illinois.edu/ atmos/statecli/newnormals/newnormals.htm>

Boone, C.G., M.L. Cadenasso, J.M. Grove, K. Schwarz, and G.L. Buckley. 2010. Landscape, vegetation characteristics, and group identity in an urban and suburban watershed: Why the 60s matter. Urban Ecosystems $1-17$.

Borchert, J.R. 1950. The climate of the central North American grassland. Annals of the Association of American Geographers 40:1-39.

Bowles, M., M. Hutchison, and J. McBride. 1994. Landscape pattern and structure of oak savanna, woodland, and barrens in northeastern Illinois at the time of European settlement. pp. 65-74 in Proceedings of the North American Conference on Savannas and Barrens., Illinois State University, Normal, Illinois, U.S.

Bowles, M., M. Jones, J. McBride, T. Bell, and C. Dunn. 2005. Temporal instability in Chicago's upland old growth forests. Chicago Wilderness Journal 3:5-16.

Bowles, M.L., and M.D. Jones. 2008. Chronological Change in Old Growth Forests of the Chicago Region. Report to the Illinois Department of Natural Resources and the Chicago Wilderness. The Morton Arboretum, Lisle, Illinois, U.S.

Buckley, D.S., J. Isebrands, and T.L. Sharik. 1999. Practical field methods of estimating canopy cover, PAR, and LAI in Michigan oak and pine stands. Northern Journal of Applied Forestry 16:25-32.

Cadenasso, M.L., S.T.A. Pickett, and K. Schwarz. 2007. Spatial heterogeneity in urban ecosystems: reconceptualizing land cover and a framework for classification. Frontiers in Ecology and the Environment 5:80-88

Elmqvist, T., C. Folke, M. Nyström, G. Peterson, J. Bengtsson, B. Walker, and J. Norberg. 2003. Response diversity, ecosystem change, and resilience. Frontiers in Ecology and the Environment 1:488-494.

Fehrenbacher, J.B., D. Alexander, I.J. Jansen, R.G. Darmody, R.A. Pope, M.A. Flock, E.E. Voss, J.W. Scott, W.F. Andrews, and L.J. Bushue. 1984. Soils of Illinois. Bulletin 778. Urbana-Champaign, Illinois: University of Illinois at Urbana Champaign College of Agriculture Experiment Station and Soil Conservation Service, S.S. Department of Agriculture.

Grove, J.M., M.L. Cadenasso, W.R. Burch, S.T.A. Pickett, K. Schwarz, J. O'Neil-Dunne, M. Wilson, A. Troy, and C. Boone. 2006. Data and methods comparing social structure and vegetation structure of urban neighborhoods in Baltimore, Maryland. Society and Natural Resources 19:117.

Haack, R.A., F. Hérard, J. Sun, and J.J. Turgeon. 2009. Managing invasive populations of Asian longhorned beetle and citrus longhorned beetle: a worldwide perspective. Annual Review of Entomology 55:521. 
Hintze, J. 2003. NCSS 2004 Statistical Software, Kaysville, Utah, U.S.

Iverson, L.R., and E.A. Cook. 2000. Urban forest cover of the Chicago region and its relation to household density and income. Urban Ecosystems 4:105-124.

Law, J.R., P.S. Johnson, and G. Houf. 1994. A crown cover chart for oak savannas. TB-NC-2. US Dept. of Agriculture, Forest Service, North Central Forest Experiment Station.

Manies, K L., and D.J. Mladenoff. 2000. Testing methods to produce landscape-scale presettlement vegetation maps from the US public land survey records. Landscape Ecology 15:741-754.

Manies, K.L., D J. Mladenoff, and E.V. Nordheim. 2001. Assessing large-scale surveyor variability in the historic forest data of the original US Public Land Survey. Canadian Journal of Forest Research 31:1719-1730.

Martin, P.H., and P.L. Marks. 2006. Intact forests provide only weak resistance to a shade tolerant invasive Norway maple (Acer platanoides L.). Journal of Ecology 94:1070-1079.

McBride, J.L., and M.L. Bowles. 2001. Vegetation pattern of DuPage and Will counties at the time of European settlement. In: C. Peterson (Ed.). Proceedings of the 12th Northern Illinois Prairie Conference. College of DuPage, Glen Ellyn, Illinois, U.S.

McBride, J.R., and D.F. Jacobs. 1986. Presettlement forest structure as a factor in urban forest development. Urban Ecology 9:245-266.

McCune, B., and M.J. Mefford. 2006. PC-ORD. Multivariate Analysis of Ecological Data. MjM Software Design. Gleneden Beach, Oregon, U.S. Version 5.2.

McCune, B., and J.B. Grace. 2002. Analysis of Ecological Communities. MjM Software Design, Gleneden Beach, Oregon, U.S.

McPherson, E.G., D. Nowak, G. Heisler, S. Grimmond, C. Souch, R. Grant, and R. Rowntree. 1997. Quantifying urban forest structure, function, and value: The Chicago Urban Forest Climate Project. Urban Ecosystems 1:49-61.

McPherson, E.G., D.J. Nowak, and R.A. Rowntree. 1994. Chicago's urban forest ecosystem: results of the Chicago Urban Forest Climate Project. U.S. Dept. of Agriculture, Forest Service, Northeastern Forest Experiment Station.

Nowacki, G.J., and M.D. Abrams. 2008. The demise of fire and "mesophication" of forests in the eastern United States. BioScience $58: 123-138$

Nowak, D.J. 1993. Historical vegetation change in Oakland and its implications for urban forest management. Journal of Arboriculture 19:313-319.

Nowak, D.J. 1994. Understanding the structure of urban forests. Journal of Forestry 92:42-46.

Nowak, D.J., and D.E. Crane. 2000. The Urban Forest Effects (UFORE) model: quantifying urban forest structure and functions. In: M. Hansen and T. Burk (Eds.). Integrated tools for natural resources inventories in the 21st century. Gen. Tech. Rep. NC-212. St. Paul, MN: U.S. Dept. of Agriculture, Forest Service, North Central Forest Experiment Station. 714-720.

Nowak, D.J., D.E. Crane, J.C. Stevens, R.E. Hoehn, J.T. Walton, and J. Bond. 2008. A ground-based method of assessing urban forest structure and ecosystem services. Arboriculture \& Urban Forestry 34:347-358.

Nowak, D.J., J.E. Pasek, R.A. Sequeira, D.E. Crane, and V.C. Mastro. 2001b. Potential effect of Anoplophora glabripennis (Coleoptera: Cerambycidae) on urban trees in the United States. Journal of Economic Entomology 94:116-122.
Nowak, D.J., M.H. Noble, S.M. Sisinni, and J.F. Dwyer. 2001a. People and trees: Assessing the U.S. urban forest resource. Journal of Forestry 99:37-42.

Nowak, D.J., R.A. Rowntree, E.G. McPherson, S.M. Sisinni, E.R. Kerkmann, and J.C. Stevens. 1996. Measuring and analyzing urban tree cover. Landscape and Urban Planning 36:49-57.

Pickett, S.T.A., M.L. Cadenasso, J.M. Grove, P.M. Groffman, L.E. Band, C.G. Boone, W.R. Burch, Jr., C.S.B. Grimmond, J. Hom, and J.C. Jenkins. 2008. Beyond urban legends: An emerging framework of urban ecology, as illustrated by the Baltimore Ecosystem Study. BioScience 58:139-150.

Poland, T.M., and D.G. McCullough. 2006. Emerald Ash Borer: Invasion of the Urban Forest and the Threat to North Americas Ash Resource. Journal of Forestry 104:118-124.

Rowntree, R.A. 1984a. Ecology of the urban forest--Introduction to part I. Urban Ecology 8:1-11.

Rowntree, R.A. 1984b. Forest canopy cover and land use in four eastern United States cities. Urban Ecology 8:13-27.

Rowntree, R.A. 1986. Ecology of the urban forest--Introduction to part II. Urban Ecology 9:229-243.

Santamour, F.S., Jr. 2004. Trees for urban planting: diversity uniformity, and common sense. pp. 57-65 in 7th Conference of the Metropolitan Tree Planting Alliance (METRA).

Transeau, E.N. 1935. The prairie peninsula. Ecology 16:423-437.

U.S. Census-Bureau. 2011. 2010 Census Data. <http://2010.census. gov/2010census/data/>.

Walker, J.S., N.B. Grimm, J.M. Briggs, C. Gries, and L. Dugan. 2009. Effects of urbanization on plant species diversity in central Arizona. Frontiers in Ecology and the Environment 7:465-470.

Willman, H.B. 1971. Summary of the geology of the Chicago area. Circular 460. Urbana, Illinois: Illinois State Geological Survey.

Woodall, C., D. Nowak, G. Liknes, and J. Westfall. 2010. Assessing the potential for urban trees to facilitate forest tree migration in the eastern United States. Forest Ecology and Management 259:1447-1454.

Zipperer, W.C. 2002. Species composition and structure of regenerated and remnant forest patches within an urban landscape. Urban Ecosystems 6:271-290.

Zipperer, W.C., S.M. Sisinni, R.V. Pouyat, and T.W. Foresman. 1997. Urban tree cover: An ecological perspective. Urban Ecosystems 1:229-246.

Robert T. Fahey (corresponding author)

The Morton Arboretum

Lisle, IL 60532, U.S.

rfahey@mortonarb.org

Marlin L. Bowles

The Morton Arboretum

Lisle, IL 60532, U.S.

Jeanette L. McBride

The Morton Arboretum

Lisle, IL 60532, U.S. 
Résumé. Les forêts urbaines fournissent d'importants services écosystémiques, mais la composition en espèces et la structure de la canopée influencent l'approvisionnement de ces services ainsi que la stabilité à long terme de la canopée urbaine. Deux ensembles de données mesurées de territoire (relevés de territoire avant occupation et recensement d'arbres urbains) ont été utilisées afin d'explorer les relations entre l'utilisation moderne du territoire, la végétation au stade précolonial et la structure de la canopée forestière urbaine, la taille de cette structure et sa composition au sein de la région métropolitaine de la ville de Chicago en Illinois (États-Unis). La végétation présente avant l'occupation du territoire et l'utilisation moderne du territoire se combinent pour influencer la composition de la forêt urbaine et sa structure. Les superficies forestières modernes avec une forte dominance d'espèces indigènes, une structure et un couvert végétal complexes ont été associées avec une végétation forestière (plutôt qu'une prairie) au stade précolonial. Les chênes (Quercus spp.), qui dominaient les forêts précoloniales et fournissaient une grande valeur de services écosystémiques en raison de leur grande stature et de leur valeur pour la faune, ont été fortement associées aux superficies forestières précoloniales et aux superficies naturelles modernes. La région de Chicago est dans une un état de transition car la composition et la structure des classes de dimensions élevées sont fortement liées à la végétation préurbaine. Dans le futur, cet aménagement va sans doute expérimenter une transformation de la domination du chêne vers des espèces de plus petites dimensions, opportunistes, non-indigènes et de courte durée de vie. Cette transformation, avec les changements climatiques et l'introduction de parasites exotiques, pourraient résulter en une forêt urbaine avec un potentiel réduit à fournir d'importants services écosystémiques.

Zusammenfassung. Urbane Forstflächen liefern wichtige Voraussetzungen für funktionale Ökosysteme, aber die Artenzusammensetzung und Kronenstruktur beeinflussen das Ausmaß dieses Services und die Langzeit-Stabilität der urbanen Kronenfläche. Zwei Datensätze auf Landschaftsbasis (Erhebung von Daten zur Vor-/bzw. Frühbesiedelung und eine urbane Baumzählung (Zensus)) wurden verwendet, um die Beziehungen zwischen moderner Landnutzung, Frühbesiedlungsvegetation und urbaner Kronenflächenstruktur, Größenstruktur und Zusammensetzung in der Metropole von Chicago, Illinois, USA zu untersuchen. Die Frühbesiedlung und moderne Landnutzung ergänzten sich im Einfluss auf die urbane Kronenflächenstruktur. Moderne Forstflächen mit einer hohen Dominanz nativer Baumarten, Kronenfläche, und struk- tureller Komplexität wurden mit Forst- (eher als Steppen-)Vegetation in früh besiedelten Landschaften verglichen. Eichenarten, die auf den früh besiedelten Forstflächen dominieren und wegen ihrer großen Struktur und Lebensraumangebot für viele Wildarten einen hohen Beitrag zum Ökosystem liefern, wurden stark assoziiert mit früh besiedelten Forstflächen und modernen naturnahen Arealen. Die Region Chicago befindet sich in einem Stadium der Veränderung, wobei die Zusammensetzung und Struktur von größeren Klassen eng verbunden mit der Vegetation früh besiedelter Räume ist. In der Zukunft wird diese Landschaft wahrscheinlich einen Wechsel in der Dominanz von großen Eichen hin zu kleineren, kurzlebigen, nicht-nativen und opportunistischen Arten erleben. Dieser Wechsel, zusammen mit klimatischen Veränderungen und die Einführung von exotischen Arten könnte zu einem urbanen Forst mit reduziertem Potential für die Bereitstellung ökologischer Vorteile führen.

Resumen. Los bosques urbanos proporcionan importantes servicios de los ecosistemas, pero la composición de especies y la estructura del dosel influyen en la provisión de estos servicios y la estabilidad a largo plazo del dosel urbano. Se utilizaron dos conjuntos de datos a escala de paisaje (encuestas de tenencia de la tierra y un censo de árboles urbanos) para explorar las relaciones entre el uso actual de la tierra, vegetación anterior, y estructura del dosel del bosque urbano, tamaño estructural y la composición en la region metropolitana de Chicago, Illinois, Estados Unidos. La vegetación pre-establecimiento y el uso moderno de la tierra combinados influyen en la estructura y composición del bosque urbano. Las áreas boscosas modernas con alta dominancia de especies nativas, cobertura y complejidad estructural se asociaron con vegetación forestal (en lugar de pradera) en el paisaje pre-establecimiento. Los robles (Quercus spp.), los cuales dominaron los bosques pre-establecimiento y proporcionan alto valor de servicio al ecosistema debido a su gran tamaño y el valor de la vida silvestre, estuvieron fuertemente asociados con zonas de bosque pre-establecidas y áreas naturales modernas. La región de Chicago se encuentra en un estado de transición donde la composición y estructura de clases de tamaño más grandes están fuertemente ligadas a la vegetación pre-urbana. En el futuro, este paisaje es probable que experimente un cambio en la dominancia de encinos a pequeñas especies no nativas y oportunistas. Este cambio, junto con el cambio climático y la introducción de plagas exóticas, puede resultar en un bosque urbano con menor potencial para proporcionar servicios por parte de los ecosistemas más importantes. 